\title{
THE CROATIAN PHILSOPHER FRANE PETRIĆ ON THE PHYSICAL AND METAPHYSICAL NATURE OF LIGHT
}

Anto Mišić S.J.

UDK 118 Petrić, F.

\section{Introduction}

Throughout history of mankind, light has aroused religious, philosophical, and scientific interest. The beginnings of metaphysics of light can be found in Indian and Iranian myths involving the sun, which later spread into the religious and philosophical thought of the ancient world. Divine properties were attributed to natural light, which resulted in considerable confusion, elucidation of which was attempted within various philosophical systems. Plato confronted reality of the senses to reality of the intellect, thus light of the senses should also have its ontological source in higher intelligible reality. Others, among them various pantheistic systems, negated the substantial difference between the sensorial and the intelligible. Neo-Platonists approached the problem through a system of emanation from the One, who is absolute and transcendent and starting from whom, by gradual descent, a sensorial reality is reached. Speculations in connexion with light continued througout Christian literature, starting from the writings of the New Testament, of the Greek and Latin Church fathers into later Christian literature. Many Christian authors considered Platonic and neo-Platonic images, terminology, and solutions with sympathy. Nevertheless, a sensory light does not originate in intelligible light which has another nature, being the creation of God, not his emanation. In Christian literature, views on sensorial light rarely rise above the symbolical, metaphorical meaning.

Light is the fundamental theme of Petrić's ${ }^{1}$ philosophical system, which is not the case in his contemporary fellow-philosophers Telesi or Bruno. Pre-

1 Frane Petrić (Franciscus Patricius - but various spellings of his surname also occur, i. e. Patritius; Patrisio, Patrizio, Patrizi, Petrić, Petrišević) was born on April 25, 1529 in the hamlet of Cres on the island of the same name in the northern Adriatic. In an autobiographical letter he claimed to be of a royal descent, his ancestors having fled from Bosnia before the Turks. No doubt exists, however, about his Croatian descent, a fact passed over in silence by nearly all histories of philosophy and world encyclopaedias. He started his primary education in his home town, but already at the age of nine he joined his uncle, the owner of a warship, and took part in battles against the Turks. The uncle had wished his nephew to 
cisely since light is so important in his philosophical discourse - as he has especially elaborated in his main work "Nova de universis philosophia" 2 we wish to point out this theme as the most characteristic one in the work of this renaissance neo-Platonic philosopher. ${ }^{3}$ Petrić presented light as the original Good which manifests itself through radiance in its otherness as their driving force. The entire universe is permeated and animated by light which from the One, as original principle, descends through the different grades of beings whom it enables to participate in the same nature. Through light, Petrić sought to overcome the actual difference between the sensorial and the intelligible worlds, therefore, in his philosophical thought, light never represented a metaphor or a sensorial image of intelligible processes, but a reality uniting the world.

become a merchant, his father had hoped he would be a doctor, but he dedicated himself to philosophy. He contined his studies in Ingolstadt where a relative of his helped him: the famous reformator Matthias Flacius Illyricus. Petrić later went to Padua, studied medicine, but eventually returned to philosophy. He was the first professor of Platonic philosophy in Ferrara, afterwards in Rome, whence he was invited by his fellow-student Ippolito Aldobrandini, at that time pope Clement VIII. His arrival in Rome was not under a lucky star because his principal work "Nova de universis philosophia" (NUPh) came under severe attack. It was put on the Index of prohibited books and its distribution was forbidden. In spite of Petrićs courageous and resolute defense, the work was condemned and ordered to be destroyed. A short time after, ill and disillusioned, Petrić died on February 7, 1597 and was buried in the church of St. Onophrius in Rome. His tomb exists to the present day.

2 In his principal work "Nova de universis philosophia” (NUPh) (1591) Petrić had attempted to give a systematic, new, and original interpretation of the universe as the title of the book shows. NUPh consists of four basic parts: PANAUGIA, PANARCHIA, PAMPSYCHIA, and PANCOSMIA. "Panaugia" deals with physical and metaphysical characteristics of light based on three fundamental concepts: Lux (light) as the mark of the originals state, whereas lumen (radiance) is diffused light far from its source, both of them are connected by rays. The subject of "Panarchia" is Petric's neo-Platonic hierarchy of beings who originate in God (defined as One, Good, and Light), disposed in a descending range of perfection graduated into nine grades: unitates, essentiae, vitae, mentes, animae, naturae, qualitates, formae, corpora. In "Pampsychia" Petrić suggested, according to the neo-Platonic tradition, his own theory of the soul as mediator between the sensorial and the intellectual spheres. "Pancosmia", the most extensive part of his work, deals with the physical world. It begins with an analysis of four basic principles: space, radiance, warmth, and fluid, continuing extensively with astronomy, meteorology, geography, etc. This work of F. Petrić is a remarkable synthesis of renaissance knowledge, so that it is not only of interest to philosophy, but also to history of science.

3 The diversity of Petrićs interests is evident from his numerous books, either published or in manuscript form, which are being kept in various major Italian libraries. His first printed work was a small political treatise "Città felice" (Happy city). Petric was only 22 at the time. His early work is "Della historia diece dialoghi" (Ten dialogues on history) (1560) which was considered at the time as a new kind of literature and can be understood as the percursor of later literature on philosophy of history. "Discussiones peripateticae" (1571) contain sharp and polemic criticisms of Aristotle. Besides philosophical subjects, Petric treated other subjects, such as rhetorics, poetry, the art of war, etc. 


\section{The nature of Light}

In his endeavour towards a systematic and unique interpretation of the universe and in his search for a principle of unity of the material and ideal world, Petrić found one of his main physical and metaphisical principles in the corporal-non-corporal structure. According to Petrić, philosophy is a study of wisdom founded on order. All cognition has its origin in the mind and its beginning in the senses, the most important being the sense of sight; the first thing perceived by sight is light and radiance through which it determines differences among things. ${ }^{4}$ Petrić thus established sight as the chief sense and radiance as the first perceived reality, two basic principles of his philosophy. Through the direct sensorial phenomenon of light, he wished to discover and attain the first cause.

In relation to light and on the ground of experience, we perceive three varieties of bodies: luminous ones, transparent ones, and dark ones. According to Petrić, luminous bodies are the sun, the stars, and fire, they are sources of light. The opposite are dark bodies (the Earth, clouds, the moon) which do not contain light but produce darkness. Transparent bodies (ether, air, water) contain neither light nor darkness but absorb both these opposite realities, they are places where they mix.

Petrić began his investigations of light by a discussion on radiant bodies he defined as follows: "ea sunt, quae semper lucent. Lucent autem semper, quae lucem propriam sibiq, innatam, \& connatam habent. vt Sol, sidera, ignis." 5 They do not produce the same radiance but three distinct corporal radiances of which none is the first, the source of the others. Distiction between corporal sources of light pre-suppose a single source, since before each quantity and number ${ }^{6}$ a unity (unitas) must exist as a base and element of every quantity. ${ }^{7}$ This initial light cannot be any of those which are first in the endless chain of lights. Multiplication of the commencements provides no solution to any problem whatsoever, neither to the question on the origin of light: "Ergo vna, erit omnium, lux prima." ${ }^{8}$ Should we seek for the initial source of

"Visui prima, \& primo cognitia, sunt lux, \& lumen. Eorum ope, \& opera, plurimae patescunt rerum differentiae. (...) Philosophia ergo, lucis, luminis, admirationis, contemplationis proles est verissima" NUPh, Panaugia f. 1b-c.

5 NUPh, Pnaugia f. $1 \mathrm{~d}$.

6 This conclusion of Petrić's remains unclear since he did not explain the difference betwee a "numerus" and "multitudo" in his reference to different kinds of corporal light. Cf. NUPh, Panaugia f. ld.

7 “Ante vero numerum \& multitudinem omnem, est vnitas. Neque vlla, aut est, aut esse potest multitudo, quae a sua non profluat vnitate” NUPh, Panaugia, f. 1d.

8 NUPh, Panaugia f. 1d. 
light in anything material, we would be obliged to multiply a series of these sources, which is impossible. Petrić, consequently, came to the conclusion that the primary source of corporal light cannot in itself be corporal, but noncorporal. ${ }^{9}$ The first substantial and subsistent light, the cause of all the others, is not corporal, but is not quite different from corporal light either - as a matter of fact, the effect retains some similarities with its cause. Visible light is the multiple image of non-corporal light in space. Spacial multiplication of light is not a negation of its true nature, but a manifestation of its otherness. It is in the nature of light to illuminate itself and others. The brightness of the first inner light is "paternum profundum", whereas its luminosity in space, i. e. "extra patris profundis", is non-corporal since the first Light is shining within it, but at the same time it is corporal, being immanent to bodies. The nature of light is, therefore, corporal - non-corporal if it is observed from space towards the source, and non-corporal - corporal if observed from the source towards space.

If the first light is the cause of all other lights, the question arises what is light in luminous bodies - substance or accident? Light in luminous bodies is no accident since an accident is something dispensable and variable, and light belongs to the essence itself of radiant bodies. ${ }^{10}$ Light in luminous bodies is not a combination of matter, nor a combination of matter and form, since matter cannot exist without a form coming from outside and, apparently, nothing can be added to light coming from outside. Rejecting these alternatives, Petrić concluded that the matter of the sun is sun, of a star is star; of fire is fire, light is their "forma substantialis". ${ }^{11}$ After establishing light as the "forma substantialis" of radiant bodies, the question remained: what is their matter?

On the grounds of observations of fire, which is wholly permeated with light as constitutive element of its essence, Petrić came to conclusion that this might also be true of the sun, stars, and heaven. ${ }^{12}$ Should this not be true,

10 "Id si nequit fieri, lux neque accidens est vllù, neque est in Sole, in astris, in igne, vt qualitas Sed est ipsis pars essentialis. At Sol, \& estra, \& ignis, corpora sunt, substantiae sunt. Ergo \& lux, ad corpora eorum constituenda pertiner, \& essentiae eorum par est principalis" NUPh, Panaugia f. 2a.

11 "Verius ergo fuerit, lucem in sole, ac sideribus, formam esse assere. Formam inquam eam, per quam res sit, \& quae rei det esse. lux enim solis, soli dat, vt sol sit: \& sine qua sol non esset sol, neque esse posset" NUPh, Panaugia f. 2c. A similar position can be found in Plotinus (cf. Enneade IV, 5, 7) but it is a different one from that of Grossateste accading to whom light is "prima forma corporalis", pre-supposing, however, "materia prima". Cf. R. Grossatesta, Metafisica della luce, a cura di Pietro Rossi, Rusconi, 1986, p. 114.

12 This manner of "proof" is frequent in Petrić's works, hecalled it "clarissima experimenta" or "geometrica necessitas". His conclusions concerning the essence of things were drawn on ground of analysis of direct sensorial and individual experiences. By aid of the concept thus 
light would, at the same time, be a form in fire and a matter in the sun and the astral bodies. The simplicity of light does not allow its own duplicity, it is, therefore, its own matter and form. ${ }^{13}$ By claiming that light in radiant bodies is both matter and form, Petrić de facto denied the ontologigal difference between matter and form: "At lux simplicissima rerù est. Non ergo duplex est, vt alia materia sit; alia sit forma. Vnica ignitur est, sibi ipsa \& materia, \& forma." 14

By establishing the corporal-non-corporal nature of light, Petrić elaborated a method of bridging the span between the corporal and the non-corporal, the material and the intelligible. Light is non-corporal - corporal if observed from the source, resp. corporal - non-corporal if observed from space towards the source. Comprehended in this manner, light can become the image of and the mediator between the corporal and the non-corporal worlds. ${ }^{15}$ Light, with its corporal and non-corporal nature, is the medial essence and substance ("mediae essentiae et substantiae"). It nature allows light to assume different forms of mediation between extremes, which is very significant for Petrić's philosophical method. With light as "mediae essentiae et substantiae" he succeeded to "descend" and "ascend" to the first cause. He thus considered the sun and the stars as "mediae essentiae et substantiae", as non-corporal in relationship to the First Light ${ }^{16}$ but, at the same time, as corporal in relationship to three-dimensional space and the material world. ${ }^{17}$

For better and easier comprehension of the nature of light, it is useful to mention Petrić's understanding of the concept of the natural being, the object of natural science. In contrast to the opinion following which perception of bodies can only be effected through sensorial qualities, Petrić claimed that

created, he drew his conclusions on the essence of everything encompassed by this concept. This has provoked much criticism of his philosophical method. Cf. F. Walkhoff, Francesco Patrizis Zeben und Werk, Bonn 1920, p. 33.

13 Petrić rejected the idea of matter in sun or stars being ether or "Quinta essentia". He considered ether to be the first transparent body and did not offer his own views on "quinta essentia" but cited the opinion of others who regarded it as non-material.

14 NUPh, Panaugia f. 2d.

15 "Lux ergo \& incoroporeorù, \& corporù aeque, simulachrum est \& imago, \& medium quoddam inter diuina incorporea, \& corporum naturam" NUPh, Panaugia, f. 2d. This position of light is similar to that which is, in the Platonic tradition, usually attributed to a mathematical body, i. e. something intermediary, between corporal and non-corporal, sensorial and intelligible.

16 Cfr. NUPh, Panaugia f 3a.

17 "Incorporeae simul, quo ad luce, \& corporeae quo ad dimensiones" NUPh, Panaugia f. 2d. Attention should be drawn to the fact that, following Petrić, the main property of natural substances lies rather in their dimensionality, than in their corporality. Thus, the difference between God and natural beings is primarily in the presence or absence of dimensionality. According to Petrić, anything placed in space is a physical body. 
natural beings are not only sensorial, material, and mobile, consisting of matter and form. He defined bodies as substances consisting of matter and form, and with three dimensions: length, breadth, and depth, as well as being visible and palpable. ${ }^{18}$ They are the starting-point of all cognition by perception. Petrić pointed out the "antitypia" (power of resistance) as the basic property of material bodies; penetration as that of mathematical and non-corporal bodies; and of both: dimensionality. This conception was the foundation for the construction of his theory on the corporal - non-corporal nature of light. Non-corporality of light is present if it is infinite and immeasurable in its instantaneous spreading through space. But by spreading in three dimensions it also manifests its corporality. For Petrić, three-dimensionality is the initial determination of natural substance, the difference between the natural and the Divine, consisting primarily of the presence or absence of dimensionality. On account of the three-dimensionality of infinite space, anything existing within it is a physical body. This is why the difference between material and non-material light lies solely in the fact that the one is in space, the other outside space, in "Paternal Depth". Visible light of radiant bodies is as a matter of fact, a non-material being which, in space, becomes physical and sensorial.

Light spreads instantaneously, permeating transparent bodies (ether, air, water) and mixing with darkness produced by dark bodies (the moon, clouds, the Earth). Radiance weakens as the distance from its source increases and as it enters into transparent and dark bodies. Light, the base of a Divine substance itself, permeating the material world becomes - as radiation a process of energetics, resulting in in motion, warmth, growth, and life, thus becoming the most suitable means of Divine creative action. God, the source and father of light, created the world with this instrument, light, which became, at the same time, the power uniting the sensorial and the intelligible world. The initial source of non-corporal light is God (lux prima), who is the source of the diffusion of light. God is the ultimate source of light in the physical world as well. It can be said that through its divine origin, light is infinite and noncorporal, but it is corporal and non-corporal if we observe it in its state of radiance. These properties render light a mediator between God and the material world.

\section{Light and the Physical Universe}

The physical universe consists of four elements: space, light, warmth, and fluor. Space is the first since everything created within it is outside the "pa- 
ternal depth"; actually, in order to exist, things must be placed in a certain space. Space, as a matter of fact, - regardless of material things - existed, empty and homogeneous, in its infinite three-timensionality. The world is situated within a limited part of space which can be regarded as identical with place. Place is, in itself, a limited and immovable part of space in which the material world is situated. Petric claimed that the principal cosmic bodies have their own places since the beginning, and the Earth is placed into the centre of the universe. The reality of space is the foundation for the possibility and existence of things and material processes, therefore a study of spacial laws plays a basic part in the perception of nature.

According to Petrić, each existing thing has a double meaning: one is enclosed in Paternal Depth, thus being absolute and unattainable, the other is open and ouside Paternal Depth, in space. According to the first, everything is unlimited and perfect in itself, according to the latter, everything is in a process of perfection. This double meaning applies to all beings and the entire universe.

The motive for emerging from one's own identity into otherness is God's goodness as creator. The initial light diffused and filled space, becomin_a means of creation. It was impossible for space to fill itself, its own dimensions, therefore radiance was the first thing that filled it, the being which was able to spread through infinite space most easily of all. However, since before the creation of space nothing existed except the Creator, the source of light cannot be anything else than God, the initial radiance and source of all radiance. ${ }^{19}$ Divine radiance is the direct source of radiance diffused inspace. At the beginning, radiance was spiritual and non-corporal, but after emerging from the Original Light, from the Paternal Depth, and entering into three-dimensional space, radiance became corporal. Dispersed radiance in space is corporal and non-corporal at the same time. ${ }^{20}$ Space and radiance are of the same kind since they are both corporal - non-corporal, possess infinite three-dimensionality, and offer no resistance. From the initial light (lux), radiance acquired the image of creative goodness, which, aided by fluid, forms the physical world: space, radiance, warmth, and fluid are bound together. As a matter of fact, although differing, they all are one oneness since they spring from the same creative source: space and radiance in a direct process, warmth and fluid being, actually, condensed radiance. Interaction of these elements result in natural bodies. Bodies have three dimensions in space, radiance renders them visible, warmth keeps them alive, and their resistance comes from fluid. Petrić's four material principles are essentially the same, but with other names. An exceptional role is played by radiance; meaning not only the visible one, but primarily cosmic energy which, through its condensation, produces 
warmth and fluid. If it remains in its original state, radiance is invisible, spreading with immeasurable speed through unlimited space. It becomes visible in stars, by further condensation it becomes warm like the sun which is, actually, a condensed fire. Through its own condensation, radiance becomes warm and fluid.

Petrić vras, therefore, convinced that cosmos was homogeneous, full of harmonious laws and matter. Fluid, which is the unity of the material world, is not empirical material but is imagined as plasma from which natural bodies originate in space. Between infinitely mobile radiance and fluid condensed it the body by warmth, a sign of equality could be put. It can, therefore, be assumed that Petrić, in his vision of the cosmos, developed an individual theory of matter as energy. Creative energy is not, however, understood in a quantitative sense, but as the creative process of Light, the fundamental principle permeating all grades of the being, giving the sense of existence and action.

\section{Conclusion}

The brilliance of initial light is in itself "paternum profundum" and radiance "extra patri profundum" - i. e. in space - is non-corporal since initial light shines within it, but is corporal as well, because it is placed in a three-dimensional space. On account of its ubiquity, light enables bonds between the opposites. In his physical-metaphysical contemplations on light, Petrić adopted terms from the Hellenistic tradition as well as metaphors "paternum profundum" and "extra patris profundum", introducing them into Christian terminology, explaining them as inner and outer Divine actions. As far as our author is concerned, this terminology had a metaphysical significance, but an ontological one as well.

From the hitherto mentioned, it can be deduced that Petrić"s "lux" is not only the sensorial image of a rational emanative process, but is original Good itself, manifested in otherness of plurality. However, Petrićs philosophical system, based on the total presence of light, extending from God "Father of Light" up to the body, is not emanative, because light did not degradatively enter into diversity and materiality, but was affirmed as the creative power. Light permeates the entire universe, corporal and non-corporal, and as main a carrier of cosmic energy becomes the base of communication throughout the universe. Physical light is only the revelation of Divine light which is the unity of physical, psychical, and spiritual processes. Petrić suggested, therefore, a monistic vision of the world, light being the base of this unity. Differences and distinctions between the sensorial and rational worlds, between matter and form, between nature and soul are but the results of the method of approach. Petrić suggested a vision of harmonious unity of the universe in which all contradictions have been overcome and have disappeared. 